\title{
Nationalized Judaism and Diasporic Existence. Jakob Klatzkin and Hans Jonas
}

\author{
Yotam Hotam
}

\begin{abstract}
This article characterizes the modern Jewish debate around Zionism as a profound political theological controversy by juxtaposing the works of two significant twentieth-century Jewish scholars, Jakob Klatzkin (1882-1948) and Hans Jonas (1903-1993). The article demonstrates that, for these scholars, the Zionist political venture was informed by a Gnostic theological message. While Klatzkin campaigned for Zionism as Gnosticism, Jonas critically challenged this link in his writings from the 1950s and 1960s. In presenting a theological reading of modern Jewish secular thought, the article transcends the political controversy between Zionists and Post-Zionists that dominated the literature in recent decades. It proposes a new horizon in the study of Jewish modern-secular thought.
\end{abstract}

Keywords: Zionism; Diaspora; Gnosis; Life Philosophy; Political Theology; Secular-Theology

\section{Introduction}

In the last twenty years, Zionism has stood in the center of an academic controversy between protectors of Jewish nationalism such as Anita Shapira and Yosef Gorny, and critics of its very legitimacy as a form of European colonialism, such as Benny Morris, Amnon Raz Krakotzkin and Avi Shlaim. ${ }^{1}$ A debate between Zionists and Post-Zionists, this profound controversy not only polarised research in favor of one ideology or the other; it also corrupted it. More acutely, the debate took the form of a kind of trench warfare between two rival political camps. As such, the debate literally brought the study of Zionism to a state of virtual stagnation, since the field of study by and large became a kind of ideological zero-sum game.

This article seeks to transcend the present state of affairs in the study of Zionism. For this purpose, unlike former studies, Zionist or Post-Zionist, which usually treated the social, military, economic, practical, ethnic, and recently gender aspects of Zionism, this

1 This article is based on a paper presented at the international conference "Life Philosophy and Zionism" which took place on May, 21-22, 2008 at the Van Leer Institute in Jerusalem. In the paper I revisited some aspects of my recent book (Magnes 2007), which is forthcoming in German, with the publication series of the Simon Dubnow Institute, Leipzig and the V\&R publication house. I thank my colleagues Ofer Nur, and Adi Efal from the Hebrew university of Jerusalem, and Dirk Moses from the University of Sydney for their enlightening remarks on an earlier version of the paper. 
article considers the theological character of Jewish national-secular thought; it will illustrate Zionism as a specific form of political theology (Schmitt 1923). The question whether Zionism was a "good" or "bad" historical venture - a liberation movement or an oppressing colonial force - does not stand at the heart of this examination of the theological character of Zionism. Instead, it is an inquiry into the metaphysical and imaginary foundations of this historical phenomenon.

To this end, the article argues that at the heart of the Zionist political theology lies a connection between a concept of modern (i.e. a secularized form of) Gnostic theology, and the Zionist political argumentation. By juxtaposing the works of two Jewish scholars, Jacob Klatzkin (1882-1948) and Hans Jonas (1903-1993), the article demonstrates this connection between (Gnostic) theology and (Zionist) politics from the perspective of modern secular Jewish thinkers themselves. Interestingly, Klatzkin and Jonas wrote their major works concomitantly in Germany in the 1920s and 30s, when both were committed Zionists. Nonetheless, to the best of my knowledge, they were not acquainted with each other. Nor did they have any direct intellectual relations. Not surprisingly, then, these scholars have not been studied together. Yet, for precisely this reason, juxtaposing Klatzkin and Jonas can illuminate how modern Jewish minds think alike, namely how for these distinct thinkers the Gnostic specific theological message informed the national Jewish secular argument for which Klatzkin campaigned and which Jonas, in his postwar critique, wished to amend.

The juxtaposition proceeds as follows: first Jacob Klatzkin's early twentieth-century Zionist thought will be analyzed, followed by a discussion of Hans Jonas' reaction to the Zionist argument in his writings from the 1950s and 1960s. It is important to introduce Hans Jonas' re-evaluation of the Zionist political theology from this period, because those writings demonstrate a conscious turn from his own early commitment to Zionism to what I call a post-Holocaust reformulation of ethical Judaism.

\section{Jacob Klatzkin's Secular Theology}

Born in 1882, Jacob Klatzkin was a dedicated active Zionist from the early twentieth century until his death in 1948 in Switzerland. He was a student of Herman Cohen, a close friend of Albert Einstein, and contributed to numerous Jewish scholarly enterprises such as the Encyclopedia Judaica, Bulletin Juif in Switzerland, and the Eshkol publishing house in Berlin. His remarkable Hebrew translation of Spinoza (1923) was the first and until recently the only translation available. Major scholars such as Franz Rosenzweig and Gershom Scholem, for example, acknowledged the importance of Klatzkin's translation of Spinoza, albeit critically, regarding it as a key example for the secularization of a sacred essence of Hebrew (Schmidt 2000, 86).

Klatzkin's two central publications were his 1925 philosophical work The Decline of Life (Shki'at ha-Hayim) which he published in Hebrew, and Probleme des modernen Judentums, a work which detailed Klatzkin's political worldview and that Klatzkin republished between 1918 and 1930 in a number of German and Hebrew variations. Alongside these two works, in the 1920s and 1930s, he published a number of books in Hebrew, such as Thumim, Zutot, a Hebrew philosophical dictionary, and Der Erkenntnistrieb als Lebens- und Todesprinzip.

Shki'at ha-Hayim provided Klatzkin with the philosophical framework for his political argument. As such, it demonstrates Klatzkin's full reliance on Life Philosophy (Lebensphilosophie) - a post-Nietzschean philosophical approach that proliferated in the Ger- 
man-speaking sphere at the turn of the 19th and the first decades of the 20th century. As a product of life philosophy, Klatzkin's work held an element of "life" (Leben/hayim), to be the benevolent essence and the cause of being, and the opposing element of "spirit" (Geist/ruah) as the malevolent force that created the world. It further argued for a dualistic rift between the original element of life on the one hand, and the world as a creation of the spirit on the other (Klatzkin 1925, 178). In other words, Klatzkin's work maintains that in creation the world was simply divorced from the original element of life as an outcome of the intrusion of the spirit. From that point on, the history of the world is the history of ongoing detachment, alienation and decline of life, a process in which "life eradicated itself" (Klatzkin 1925, 178).

For Klatzkin, as a life philosopher, this dualistic split between life and spirit characterizes human reality in particular. Divided between original emotional and derivative rational contesting spheres, human reality is a paradigm for the cosmic process of the decline of life and the triumph of the spirit. Thus, he maintains that "with the progression of man, and the advance of knowledge, reason moves ever closer to its origin, the divine spirit of nothingness." This process, according to Klatzkin, "ends in possessing the power over the human soul, controlling it to the extent of destroying the world of the human being, the world of beings, cooling human life and killing life with the kiss of nothingness" (Klatzkin 1925, 117).

Here it is interesting to note that Klatzkin's argument does not refute a notion of historical progress in which the spirit reveals itself through world history, as Hegel for example asserted; rather, it affirms this process, but sees in it a regression (rather than progression) in which life continuously declines. Consequently, Klatzkin's tone is deeply apocalyptic, since at the end of this process lies the triumph of the spirit that is "the end of all life." Thus: "In the hour in which reason rises, being is shattered, and life is lost" (Klatzkin 1925, 180).

The theological implications of this metaphysical argument are fleshed out by Klatzkin himself. Klatzkin explicitly points to the fact that his metaphysics actually contemplate the divine. Within this context, it is important to note that Klatzkin points specifically to the Gnostic theological character of his worldview. It is essential not to regard the term Gnosis as belonging exclusively to a remote history of Western religion or Antiquity but to see it as an important element of modern discourse. Gnosis reemerged within the German intellectual milieus in the early 20th century as an important and rather common concept, when major theologians such as Adolf von Harnack, Rudolf Bultmann, and Karl Barth published their works on the Gnostic theology, and contemplated the relations between Gnosis and secular-modernity. Jewish scholars such as Martin Buber, Gershom Scholem and, of course, Hans Jonas himself took a central part in the discussion of Gnosis. Klatzkin, therefore, was not an exception, but rather aware of the intellectual trends of his time.

There are three points to be made here to better understand the connection between Klatzkin's argument and Gnosis. First, life/Leben/hayim as the essence of being is what Klatzkin refers to as "the other, estranged God" (ha-el ha-aher, ha-zar) (Klatzkin 1925, 61). This is the Gnostic theological concept of a transcendent and hidden benevolent power, which lies beyond the world as we know it, and is divorced from that world. Second, according to the Gnostic theological approach, the world was created not by this benevolent estranged God, but rather by an opposing evil creating force. Klatzkin therefore refers explicitly to this evil creator. For Klatzkin, this is a "violent" force, which brought "animosity into chaos." For Klatzkin then, "the world is created with the power of hostility and dividedness." Finally, in Gnosis cosmic dualism is especially patent in 
human reality, which is divided between the human being as part of the world and the human hidden and true godly essence, which is alienated from the world. As Mark Lilla recently argued, alienation from the world is one of the central aspects of the Gnostic theological message and was therefore one of the central issues which preoccupied modern thinkers (Lilla 2007, 164-165). For Klatzkin, then, the human being, more than anything else, reflects the cosmic state of affairs in being simply a split entity between spirit and life, between being as part of the world, and entailing a hidden true divine spark. For Klatzkin being as part of the world means rational understanding of the world, and engagement with the surroundings through reason. The hidden, true, and divine spark is, conversely, mediated through vivid emotions, intuition, or impulses. In the last and concluding part of his Shki'at ha-Hayim, Klatzkin indeed discusses the need for human liberation from the world of reason and rationality and a return to the original godly element through counter-rational emotions and intuitions - no less than an heretic revolt against the laws of the creator which governs the world, for the purpose of numinous unity between the human being and God. This numinous unity, in terms of time, is the presenteternal moment advocated by Gnostic mystic thought, in which a human instant of forgetfulness of time becomes one with the Godly eternal. Klatzkin terms this present-eternal moment as kfitzat ha-derekh (literally "a leap of the road") - that is the aptitude to leap beyond space and time, advocated within the Jewish mystical tradition.

I referred to Klatzkin's metaphysical approach as Gnostic, yet I would also like to point to its modern and thus secular character. Characterized as "Life," Klatzkin's Godly power is natural, i.e. Klatzkin's God is immanent nature. ${ }^{2}$ This is not nature as we perceive it around us; rather, it is a hidden elemental force, which is not part of the surrounding world. The hidden benevolent power is pure immanence, whereas the world as we know it is a product of a spiritual transcendent God, as defined by the Judeo-Christian religious tradition. Interestingly, in Klatzkin's theological approach, immanence and transcendence exchange places: true and original transcendence is, actually, immanence, whereas the traditional Judeo-Christian transcendent God is identical with the world around us, i.e. is immanent. The essential outcome of this crossover between immanence and transcendence is that Klatzkin's Gnostic transcendent hidden and estranged God is secularized, because it is transformed into an omnipotent, immanent force of life. Here, secularization does not mean 'emancipation' from theology, but rather a transfiguration of a theological worldview into modern context. Accordingly, Klatzkin's secular approach should be seen as a "secular-theological," as termed by the historian Amos Funkenstein (Funkenstein 1986, 12-22).

\section{Klatzkin's True and False Existence: Zionism versus Life in Exile}

How then did this type of secular theology inform Klatzkin's Zionism? Klatzkin's Probleme des Modernen Judentums demonstrates the connection. For Klatzkin, the mod-

2 It is important to note that here Klatzkin's argument is also made in order to come in terms with Spinoza. Klatzkin relates to Spinoza's Theologico-political Treatise in which he recognized a basis for his own philosophical and eventually political-theological approach, while rejecting some elements in Spinoza's philosophy he relates to him as a pillar of Jewish revival. 
ern Jewish predicament lies in a dualistic rift, represented by two types of Jewish existence. On the one hand, Klatzkin argues for a true and 'authentic' Jewish essence. This essence is for Klatzkin national i.e. political, and is represented by two aspects: "life on the land" (Hebrew: hayei aretz) and the use of the native language (Hebrew). The metaphysical term "life" is here patent in the Jewish political existence of "life on the land." Historically, Klatzkin refers here to the times in which, according to the Jewish tradition, 'Israelites' lived in one territory, before being exiled and misplaced. According to Klatzkin, this allegedly original Jewish way of life is rooted in the performance of what he termed "ancient natural religion," in which "man and nature" are one (Klatzkin 1918, 15). To the extent that Gnosis represents for Klatzkin the theology of the unity between the human being and nature (i.e. "life"), Jewish national existence (i.e. "life on the land") stands for its political (i.e. particular) realization. ${ }^{3}$ I.e., for Klatzkin, national Jewish existence represents the political realization of his secular theology because it transforms his general claim regarding "life" into a particular existence of "life on the land." From a theological perspective, this genuine Jewish reality is equivalent to what he labeled a "religion of life" (Hebrew: dat hayim). Authentic Judaism is dat hayim; national existence is the political articulation of Judaism as dat hayim, which unties the Jewish person and God.

On the other hand and in opposition to the Jewish national existence, life in exile represented for Klatzkin a false Jewish existence. This false 'Diaspora' existence is informed by the deceitful spiritual God and this deity's devious laws. From the specific Jewish point of view, the Jewish Halakhah, which is according to Klatzkin the legal and moral codex of diasporic life, reflects the laws of the cunning spiritual God. In the internal Jewish context, this view is, naturally, an utter revolt, or heresy. Klatzkin's approach radically disconnects an almighty biblical God from the God of the Jewish halakhic interpretive venture. Within these settings, he argues for example that Torat Moshe (The Teaching of Moses) was Torat Hayim (The Teaching of Life), which was corrupted, meaning "spiritualized" by the Halakhah. Thus, the halakhic laws do not represent the true essence of Jewish life under God, but rather the detachment and alienation from such original and true Jewish life. Klatzkin refers to this as a process of reshaping the Jewish existence from a genuine "Volkreligion," through the emergence of "Weltreligion," and ending with the founding of the "Sittengesetz" in which spiritual religion and law are identical (Klatzkin 1918, 15-16). For him modern Jewish secular existence, as long as it does not represent a return to a "life on the land," merely represents the continuation of this process (Klatzkin 1924, 191-197).

One central outcome of this approach - which radically distinguishes between two types of Jewish existence - is that the enemy of the "true" national "Jew" is a "false" exile Jew. Indeed, the "false Jew" is a sheer enemy of life, along the lines advocated by the life philosopher and radical anti-Semite Ludwig Klages (1872-1956) for example; on the other hand, a "true Jew" is the pure cosmic entity that Klages himself was looking for. The Jew thus represents both sides of the theological coin. Klatzkin's Zionist approach differentiates at this point between two types of political theologies. The Halakhah and

3 Also see for example his Thumim, Berlin: Eschkol 1925, 27, and idem "An Essay on Judaism With Respect to Ancient Religions" (Hebrew Original: Ma'amar al ha-Yahadut legabei ha-Datot ha-Kadumot), unpublished text, in: Zionist Archive, Jerusalem, A:40 22/29. 
eventually, the modern secularization of the ethics and moral codes of the spiritual God represent a false political theology. Conversely, the Jewish national existence, the political realization of the theological numinous unity between Jewish existence and God, represents a true political theology.

Furthermore, it is important to note that for Klatzkin the "true Jew" is only conceivable as a national, i.e. political being. This being was lost during exile, because exile, or diasporic existence means for Klatzkin a Jewish reality alienated and detached from the original (national) "life on the land." This absent political being is the essence to which Jewish existence should return. Zionism therefore means, for Klatzkin, a mere return to what was forgotten during exile: namely a return to a genuine national Jewish existence. Klatzkin terms this true Jewish national existence "secular" (Hebrew: hagdarat hulin). Klatzkin's "secular" nonetheless is a dialectical concept: heretic with respect to the God of creation and the Jewish political existence under this God, but at the same time theological in its reliance on a modern Gnostic worldview. This does not mean that Klatzkin's Zionism is not secular; rather, it demonstrates secular thought as a type of transfigured theology. Accordingly, Klatzkin's Zionism can be seen - in a play on Gershom Scholem's words - as 'conversion through heresy' (Scholem 1937, 347-392).

Klatzkin's concept of a national Jewish existence, though defined as a return to 'original' Jewish nature, is in itself an example for the absence of such original Jewish essence. Or polemically: Klatzkin's call for a return to the original Jewish life is anything but originally Jewish. The best way to illuminate this last point is to refer to Eric Voegelin's analysis of the Aristotelian concept of "mature man" (spoudaios). In his seminal New Science of Politics published in 1952, Voegelin, a Catholic political- philosopher, claimed that Aristotle's "mature man" is the person who can reveal universal truth out of his own subjective experience (Voegelin 1952, 64). What is important for Voegelin is not whether Aristotle held to concepts such as "universal" and "subjectivity" as we understand them within the modern context; rather, he was interested in making a point regarding the connection between the human person and truth. For Voegelin therefore, the Aristotelian "mature man" symbolizes the connection between acute subjectivity (of the human person) and universality (truth) (Voegelin 1952, 65-70). For Klatzkin, the Jewish subject represents the acknowledger of universal (hidden) truth out of its own subjective national essence. Thus, based on Voegelin's analysis, this subject echoes the Aristotelian concept of "mature man." To put it bluntly, Klatzkin's 'authentic' national Jew is a Hellenistic ideal person. In the same vein, it is possible to see in Klatzkin's theological revolt against the halakhic law the continuation of the theological revolt commonly attributed to Paul. Yet, Klatzkin turned against Christianity the same way it rebelled against the Jewish Halakhah. After all, according to Klatzkin, both Christianity and halakhic Judaism follow the authority of a devious spiritual God. Klatzkin fiercely argued against the Pauline theology, and yet at the same time adapted a Pauline revolt against what Freud, Lacan and others have labeled "the law of the father." The outcome of this complexity is a paradox in which Klatzkin held to an anti-Pauline approach, which regarded itself as originally Jewish, and yet this approach is unthinkable without the Pauline theological revolution - a revolution which, according to Klatzkin himself, is anything but authentically Jewish. 


\section{The Theology of Hans Jonas: Transcendence within Immanence}

Born in 1903, Jonas was a generation younger than Klatzkin. In the 1920s, he was one of Heidegger's prominent students. Under Heidegger's (and Rudolf Bultmann's) supervision, Jonas presented a pivotal study of the Gnostic theology of late Antiquity, which is still considered to be authoritative today. At the same time, like many of his GermanJewish contemporaries, such as Hannah Arendt, Leo Strauss and Gershom Scholem, Jonas was a devoted Zionist. There is a lot to be said about the complex connections between Heidegger, Zionism, and Gnosis in Jonas' work from these early years. Especially in the light of the fact that historians such as Richard Wolin for example, overlooked the relations between these three issues (Wolin 2001). And yet, the fact that these three issues were connected in Jonas' own eyes is even more obvious when we turn to look at his postwar work, since this work was designed to distance Jonas equally from Heidegger, Gnosis and Zionism. Also sprouting from Jonas' reaction to the Holocaust, his postwar endeavors to reassess his early thoughts were mainly visible in his formulation of a new philosophy of life, which he characterized as a philosophy of the organic life form.

The following demonstrates a core concept in Jonas' postwar philosophy of life, and how it illuminates his rework of Gnosis and of Zionism. I start with Jonas' 1966 publication The Philosophy of the Organic Life Form. This book presents Jonas' thoughts from the 1950s and 1960s, a suitable point of departure.

In this work, Jonas was interested in reflecting philosophically on what the astrophysicist Martin Rees has labeled the universe's progression "from Big Bang to Biospheres", meaning from the moment of creation to the emergence of life (Rees 2007, 3). Jonas was interested not only in reflecting on the emergence of life out of the cosmic chain of events in general but also (and more profoundly) in elaborating on the appearance of human rationality out of the organic (and unconscious) life forms. Like Klatzkin, then, Jonas starts with a speculation concerning the cosmogonic moment of creation. Thus, Jonas takes on a central issue of early 20th century life philosophy that is the leap from the distinct elemental force of life to the appearance of reason, or from monistic cosmic point of departure in which there is only a single force of life, to a dualistic cosmos, which is characterized by the struggle between life and reason.

Here, as in Klatzkin's case, theology appears to be essential to Jonas' philosophical speculations concerning the moment of creation. According to Jonas, "in the beginning, for unknowable reasons, the ground of being, or the Divine, chose to give itself over to chance and risk and endless variety of becoming." It is in this moment that for Jonas God has entered "the adventure of space and time" (Jonas 1966, 275).

The question is, of course, what does it mean that God has entered the adventure of space and time? Obviously, it means a rejection of Gnostic dualism, in which God and the world are disconnected in creation. At the same time, however, it does not mean that Jonas returned here to monism in any simple sense. Rather, Jonas' speculation concerning God's entering the world, aimed at intertwining dualism and monism together, integrating contesting worldviews into one master theological theory. For Jonas, such a master theological theory represents "a third road [...] one by which the dualistic rift can be avoided and yet enough of the dualistic insight saved to uphold the humanity of man" (Jonas 1958, 340).

For this purpose, Jonas presents a twofold theological speculation. On the one hand, and following Gnosis, Jonas asserts that in creation, the world is indeed abandoned by God, to maintain its existence with no divine providence. Thus, he argues that "no un- 
committed or unimpaired part [of God] remained to direct, correct, and ultimately guarantee the devious working-out of its destiny in creation" (Jonas 1966, 275). In the "Big Bang," the moment of creation, world and God were disconnected. From that point on, the worldly matter, once created, is guided by its inner (immanent) forces and physical laws, with no divine supervision. God became exiled from the world. This is a Gnostic conclusion that could also be seen as Jonas' version of Nietzsche's "death of God," as well as Jonas' play on the Jewish mystical approach in which God created the world through self-diminution (tzimzum).

On the other hand, and in following monism, Jonas argues for a particular presence of God within the world. This godly presence is not characterized by a simple dominance over the world (monotheism), or unity with it (pantheism); it is also not disclosed in the form of a hidden spark exclusive to the human being (Gnosis). Rather, this presence according to Jonas is manifested in God's message encoded into the world, that is, into nature as such. More of a godly desire, hope and trust invested into the world, than a divine control and influence over it, God's message is ingrained into the world in the form of "Cosmogonic Eros" - a concept that Jonas adopted in a later article in the 1980s from the writings of Ludwig Klages (Jonas 1986). Nature operates according to its immanent, indifferent, physical laws, and organic self-guidance, and yet these nonetheless echo God's desire. In this approach, natural law is imprinted by godly law, but with no godly control, guidance, or authority - a theological concept of godly presence, devoid of divine providence. I.e. though God is detached from the world, the godly "Eros" which Jonas adopts from life philosophy still acts in the world through "the unconscious drift of immanence." It is in this specific sense that Jonas' God is not only transcendent, but concurrently immanent within the world.

In this theological model, Jonas simply fixed the presence of transcendence within the world, or of transcendence within immanence. This combination certainly reflects Jonas' specific postwar reaction to Heidegger's philosophy. It also demonstrates his reworking of the Gnostic dualism, which he upholds and negates concurrently. God is absent from the world, yet as a vital force of "life," it is present at the same time. It is a kind of a "present-absent" divinity - a notion that stood in the focal point of postwar thought in general - which for Jonas is informed by the Gnostic theology only in order to amend it. The outcome is characterized not by a tension between monism and dualism, as for example in Klatzkin's case, but rather by the integration of the two together.

It is interesting to note that a divinity, which has no control over the world, can not be regarded as 'omnipotent' in the fullest sense of the word. Indeed, Jonas argues in his famous lecture Der Gottesbegriff nach Auschwitz that his new concept of God refers to a 'non omnipotent' God (Jonas 1984). It is a type of transcendent power which is present in the world not in monotheistic notions of commandment and providence, but rather in existential terms of openness and care. According to Jonas, this deity did not prevent Auschwitz "not because he did not want to, but because he could not" (Jonas 1984). It is also interesting to note that a present-absent God, though articulated in order to respond to Gnostic mysticism, is a paradoxical union of oppositions characteristic of the same mystical tradition of thought which informed Klatzkin's worldview, for example. For how can 'being' be detached from the world, and yet ingrained into it at the same time? In a play on Max Weber's concept of secularization as disenchantment of the world, Jonas' own secular approach might thus be labeled an opposite re-enchantment, i.e. mystification, of the world.

Finally, it is important to recall that Klatzkin's approach accepted the Hegelian scheme which referred to the revelation of the spirit through world history, yet inverted 
the approval of this process to a disapproval of its end result (the decline of life). Jonas' approach can be seen as a double play on Hegel and Klatzkin. It argues favorably for a Hegelian concept of progression through history, but what is revealed through this process is the Eros of Lebensphilosophie. In this way, Jonas' approach inverts Klatzkin's Lebensphilosophie pessimism to a kind of optimism in which Life does not decline, but rather has the potential to be realized.

\section{Jonas' Ethical Judaism: Diaspora as the Universal Essence of Judaism}

We have gained an understanding of how Jonas' postwar reworking of life philosophy is intertwined with his conscious response to Gnostic theology. How then did Jonas' postwar speculations also reflect his reaction to Zionism, or what I label as his swing from National Jewish identity to a new formulation of ethical Judaism, which favors a Jewish Diasporic existence.

The answer to this question lies in the fact that Jonas himself explicitly connected between his theological speculations and Judaism. As Jonas' biographer Christian Wiese has argued "one can not ignore the Jewish dimension without missing a significant share of Jonas' own biographical experience and philosophical intentions" (Wiese 2007, xxiii). Wiese shows how Jewish religious concepts such as rotze ba-hayim ("he who wills life") which accentuated the importance of life within the Jewish tradition were of major importance for Jonas. Though not mentioned by Jonas himself, I would like to add that the Jewish concept of pikuah nefesh - the suspension of all laws, in a case of life-threatening "state of emergency" - is another concept that may have served Jonas' argument. Be that as it may, according to Jonas, "some equivalent of the meaning" of the Jewish traditional concepts "must be preserved if we are still to be Jews and, beyond that special concern of ours, if there is still to be an answer to the moral quest of man" (Jonas 1968, 15).

For sure, in looking for what he termed as "an equivalent meaning" of the Jewish traditional concepts, Jonas means a modern secular interpretation. Within this framework, Jonas argues that these Jewish concepts reflect that Judaism, in its core element, is dat hayim. Which means: a religion of Life dedicated to the perseverance of life as such. Consequently, being a modern secular Jew means a return to Judaism as dat hayim. Here, then, Jonas and Klatzkin truly agree on the essence of Judaism. Yet, Jonas' concept of dat hayim is not anchored in a modern Gnostic theological message, but rather in its reformulation; the political outcome is that at this point Jonas turns from Zionism to pro-diasporic ethical Judaism, from national Judaism to Diasporic existence. Dat hayim, a religion of life, to which a Jew must return, means for Jonas, an ethical rather than particular national essence. Accordingly, it does not command an alleged 'return' to original Jewish national existence, as Zionism argued, but rather an uncovering of the universal quest for ethical responsibility towards life as such. Such a 'universal' message can be maintained only within the context of Jewish Diasporic existence. More particularly, the 'universal' message is the essence of the Jewish being in Diaspora. Naturally, Jonas' theology of the presence of the absent God, whose message is ingrained within life, bears on his ethical imperative of preserving life. Judaism simply provides Jonas with the original theological message for which he argued, since for him the essence of the Jewish tradition is universal morality, and the object of this morality is the preservation of life. For Jonas, it is Judaism that "can help us restore a sense of reverence and awe towards nature" (Wiese 2007, 115). Being in the Diaspora fulfils the Jewish theological message, since it reflects 
the 'universal' character of the Jewish essence. For Jonas, therefore, Diaspora is the political articulation of the universal essence of Judaism; the Cosmogonic Eros commands a Jewish diasporic way of life.

It is noteworthy that as in Klatzkin's argument, the true Jewish essence for Jonas is not defined by following the laws of Halakhah - a heretic approach, if read within the Jewish specific religious context. Yet, unlike Klatzkin, who pinpointed this non-halakhic essence of the Jew in the return to a national political way of life, Jonas terms this essence responsibility towards the future. We can than say that unlike Klatzkin's approach which integrated an Aristotelian ideal person into a new concept of Jewish authentic reality, Jonas' approach adapted the Heideggerian concepts of time within the reformulation of Judaism. Yet, more importantly, Jonas' approach consciously revisits the 19th-century venture by "ethical Judaism" of grounding universal ethics in Jewish religion. Consequently, Jewish 'original' identity for Jonas is not national; it is ethical universal, 'diasporic' in essence, exactly the same way 19th-century ethical Judaism argued.

These ethical speculations provided Jonas with the foundations for the postwar 'environmental' ethics for which he campaigned in his 1977 publication Das Prinzip Verantwortung. At the heart of Jonas' new ethical approach was his formulation of the modern human responsibility toward the planet. More specifically, Jonas argued for human accountability toward the environment, as a result of the human aptitude to recover the ethical (transcendent) truth that is ingrained in the (immanent) world. As such, Jonas' postwar anthroposophic environmentalism expressed a wish to save modernity from its nihilistic fate in what he called "the age of technology." His tone was apocalyptic: "All this holds on the assumption made here that we live in an apocalyptic situation, that is, under the threat of a universal catastrophe if we let things take their present course." (Jonas 1984, 140) This apocalypse in turn supported the rise of postwar European environmental politics, the type of which still inspires political activists today, who talk rather apocalyptically about global warming. Jonas' specific environmentalism is nonetheless based on ethical Judaism; it therefore could be termed a specific attempt to ground 'the religion of environmentalism out of the origins of Judaism.'

\section{Conclusion}

"A general state of insecurity" and "intractable and essential for any genuine account of Jewish existence" (Shepperd 2006, 18). With these somewhat opposing statements, Leo Strauss reflected on Jewish 'diasporic' reality - expressing the critique, characteristic of early twentieth century Zionist thinkers, and yet, concurrently, refusing to completely ignore the significance of the 'Diaspora' for Jewish existence. To some extent, Strauss's statements, put together, flesh out the central political issue that preoccupied $20^{\text {th }}$-century Jewish scholars: an ethical, indeed metaphysical justification of the Jewish national impulse, or conversely, of sustaining Diaspora.

In juxtaposing these Jewish scholars, Jakob Klatzkin and Hans Jonas, this article discusses the dilemma that also perplexed the young Strauss; it does so by demonstrating this dilemma as a political-theological one, as both scholars argued theologically in favor or against one of the two possible Jewish political realities. In a way, both scholars use self-defeating arguments. They argue for some kind of an authentic or original essence of Jews, and yet in integrating Hellenistic, Pauline, or Heideggerian concepts, they show how the condition for the modern Jewish quest for authentic or original Jewish essence - national or diasporic - is the absence of such an authentic or original essence. Here it is 
noteworthy that the concepts 'Diaspora' and 'Exile' are analogues for Klatzkin, since both represent the antithesis of Jewish national life as defined by Zionism. For Klatzkin, 'home' and 'exile' contradict each other and 'Diaspora' is merely 'exile' in disguise. Jonas' approach is somewhat more nuanced. For him, Diaspora represents a political reality within which genuine Jewish existence can be maintained. Which is to say: for Jonas, Diaspora maintains that for Jews, 'home is exile.'

Moreover, Jonas' postwar reflections fleshed out the manner in which the Holocaust challenged the Zionist political theology, as revealed through Klatzkin's arguments. I emphasize this specific point because the Holocaust is commonly treated - in particular within the Israeli political and cultural discourse - as evidence in favor of the Zionist political argument. In the same vein, Jonas and Klatzkin demonstrate the compound connection between Zionism and environmentalism, a rather surprising connection that many Zionists and environmentalists today would probably find rather provocative, if not outright offensive. Yet, more importantly, Jonas' postwar reaction to the Zionist political theology demonstrates that saving Jewish modernity or modernity as such from its errors and self-annihilation called for the return of a previously absent God. This conclusion is rather surprising if the modern world is understood in terms of secular progression - a progression that originated, say, from a belief in an almighty power, and ended with the final disappearance and death of this Godly power - as for example many scholars today still argue. Indeed, not a stillborn God, but rather the presence of the absent one reemerged in Jonas' late modern thought, at the threshold of post-modernity. No doubt a concept of a present-absent divinity still affects diverse political and cultural phenomena today.

\section{Bibliography}

Buber, M. (1949) Two Types of Faith. Jerusalem: Bialik.

Dreyfus, H. L. (1990) Being-in-the-World: a Commentary on Heidegger's Being and Time. Cambridge, Mass.: MIT Press.

Harnack A. (1920) Marcion: Das Evangelium vom fremden Gott. Leipzig: Hinrichs.

Heidegger, M. (1928) Sein und Zeit. Halle: Niemeyer.

Hotam, Y. (2007) Modern Gnosis and Zionism: The Crisis of Culture, Life Philosophy and Modern Jewish Thought. Jerusalem: Magnes.

Jonas, H. (1932/1952) Gnosis und Spätantiker Geist. Tübingen: Vandenhoek \& Ruprecht. Jonas, H. (1958) The Gnostic Religion: The Message of the Alien God and the Beginnings of Christianity. Boston: Beacon Press.

Jonas, H. (1977) Das Prinzip Verantwortung: Versuch einer Ethik für die Technologische Zivilisation. Frankfurt am Main: Insel.

Jonas, H. (1984) Der Gottesbegriff nach Auschwitz. Eine jüdische Stimme. Tübingen: Suhrkamp.

Jonas, H. (1996) The Phenomenon of Life: Toward a Philosophical Biology. New York: Harper \& Row.

Jonas, H. (2003) Erinnerungen. Leipzig: Insel.

Klatzkin, J. (1918) Probleme des Modernen Judentum. Berlin: Schneider.

Klatzkin, J. (1923) Baruch Spinoza Hayiav, Sfarav, Shitato. Berlin: Jüdischer Verlag.

Klatzkin, J. (1924) Thumim. Berlin: Eschkol.

Klatzkin, J. (1924) Zutot. Berlin: Eschkol.

Klatzkin, J. (1925) Shki'at ha-Hayim. Berlin: Eschkol. 
Klatzkin, J. (1935) Der Erkenntnistrieb als Lebens- und Todesprinzip. Zürich: Rascher.

Lilla, M. (2007) The Stillborn God: Religion Politics and the Modern West. New York: Knope.

Rees, M. (2007) Our Cosmic Habitat. Princeton: Princeton UP.

Schmidt, C. (2000) Der häretische Imperativ. Überlegungen zur theologischen Dialektik der Kulturwissenschaft in Deutschland. Tübingen: Aisthesis.

Schmitt, C. (1922) Politische-Theologie: vier Kapitel zur Lehre von der Souveränität. München: Duncker \& Humblot.

Sheppard, E. (2006) Leo Strauss and the Politics of Exile. Waltham: Brandeis UP.

Taylor, C. (2007) A Secular Age. Harvard: Harvard UP.

Theisohn, P. (2005) Die Urbarkeit der Zeichen: Zionismus und Literatur - eine andere Poetik der Moderne. Stuttgart: Metzler.

Voegelin, E. (1952) The New Science of Politics. Chicago: Chicago UP.

Wiese, C. (2007) The Life and Thought of Hans Jonas. Boston: Brandeis UP.

Wolin, R. (2001) Heidegger's Children: Hannah Arendt, Karl Löwith, Hans Jonas and Herbert Marcuse. Princeton: Princeton UP.

Yotam Hotam is a Fellow of The F. Rosenzweig Center for German-Jewish Cultural History and Literature at The Hebrew University of Jerusalem and the editor of "Tabur: a Yearbook for Central European History, Culture, Society and Thought," published by The Koebner Center for German History at the Hebrew University of Jerusalem.

E-mail: msyotam@mscc.huji.ac.il 